\title{
Effects of freezer storage time on levels of complement biomarkers
}

\author{
Angharad R. Morgan ${ }^{1 *}$, Caroline O'Hagan', Samuel Touchard', Simon Lovestone ${ }^{2}$ and B. Paul Morgan ${ }^{1}$
}

\begin{abstract}
Background: There is uncertainty regarding how stable complement analytes are during long-term storage at $-80^{\circ} \mathrm{C}$. As part of our work program we have measured 17 complement biomarkers (C1q, C1 inhibitor, C3, C3a, iC3b, C4, C5, C9, $\mathrm{FB}, \mathrm{FD}, \mathrm{FH}, \mathrm{FI}, \mathrm{TCC}, \mathrm{Bb}, \mathrm{SCR} 1, \mathrm{SCR} 2$, Clusterin) and the benchmark inflammatory marker C-reactive protein (CRP) in a large set of plasma samples $(n=720)$ that had been collected, processed and subsequently stored at $-80^{\circ} \mathrm{C}$ over a period of 6.6-10.6 years, prior to laboratory analysis. The biomarkers were measured using solid-phase enzyme immunoassays with a combination of multiplex assays using the MesoScale Discovery Platform and single-plex enzyme-linked immunosorbent assays (ELISAs). As part of a post hoc analysis of extrinsic factors (co-variables) affecting the analyses we investigated the impact of freezer storage time on the values obtained for each complement analyte.
\end{abstract}

Results: With the exception of five analytes (C4, C9, SCR2, clusterin and CRP), storage time was significantly correlated with measured plasma concentrations. For ten analytes: C3, Fl, FB, FD, C5, sCR1, C3a, iC3b, Bb and TCC, storage time was positively correlated with concentration and for three analytes: $\mathrm{FH}, \mathrm{Clq}$, and $\mathrm{C} 1$ inhibitor, storage time was negatively correlated with concentration.

Conclusions: The results suggest that information on storage time should be regarded as an important co-variable and taken into consideration when analysing data to look for associations of complement biomarker levels and disease or other outcomes.

Keywords: Complement, Biomarker, Plasma, $-80^{\circ} \mathrm{C}$ storage

\section{Background}

Complement is an important part of innate immunity and plays a key role in inflammatory processes. The complement pathway includes more than 30 component proteins, regulators and receptors, which work together to fight infection and to clear toxic material. Concentrations of complement biomarkers in plasma have been found to be altered in a wide range of different diseases, including cancer, atherosclerosis, diabetes, inflammatory bowel disease, neurodegenerative disorders, autoimmune diseases and infections [1].

Levels of complement biomarkers are often inconsistent between different laboratories due in part to a lack of standardisation with variation occurring in sample

*Correspondence: morgana38@cardiff.ac.uk

1 Division of Infection and Immunity, School of Medicine, Cardiff

University, Heath Park, CF14 4XN, Cardiff, UK

Full list of author information is available at the end of the article collection, handling and storage [2-4]. As part of our work program assessing biomarkers in dementia, we have measured 17 complement biomarkers $(\mathrm{C} 1 \mathrm{q}, \mathrm{C} 1$ inhibitor (C1inh), C3, C3a, iC3b, C4, C5, C9, FB, FD, FH, FI, TCC, $\mathrm{Bb}, \mathrm{sCR} 1, \mathrm{sCR} 2$, clusterin) and the benchmark inflammatory marker $\mathrm{C}$-reactive protein (CRP) in a large set of plasma samples $(n=720)$ that had been collected, processed and subsequently stored at $-80{ }^{\circ} \mathrm{C}$ over a period of 4 years. Before investigating any possible association with dementia the biomarker levels were assessed for relationships with relevant co-variables that could influence the main results. Here we report our investigation of the impact of the freezer storage time on the measurement of complement biomarkers.

\section{Methods}

Samples

Samples were from the AddNeuroMed study, a crossEuropean cohort for biomarker discovery. Informed 
consent was obtained for all subjects according to the Declaration of Helsinki (1991) and protocols and procedures were approved by the relevant Institutional Review Board at each collection site. Further information regarding the cohort has been previously described $[5,6]$. This study utilised plasma samples from 720 subjects: 262 with Alzheimer's disease, 199 with mild cognitive impairment, and 259 elderly controls with no dementia.

Plasma samples were collected into clinical grade EDTA tubes $\left(\mathrm{K}_{2}\right.$ EDTA; final concentration $\left.1.8 \mathrm{~g} / \mathrm{l}\right)$ and centrifuged at $3000 \mathrm{rpm}$ for $8 \mathrm{~min}$ at $4{ }^{\circ} \mathrm{C}$. Plasma was harvested, aliquoted and then frozen at $-80^{\circ} \mathrm{C}$.

\section{Measuring the levels of clusterin, soluble complement receptor 2 and CRP}

The plasma levels of clusterin, soluble complement receptor 2 (sCR2) and CRP were determined using commercially available enzyme-linked immunosorbent assay (ELISA)-compatible antibody pairs (clusterin and CRP from R\&D systems (Abingdon, UK) (cat\# DY5874 and DY1707) and sCR2 from Sino Biological (Beijing, China) (cat\# SEKA10811)) and protocols were followed as described by the manufacturers.

\section{Measuring the levels of soluble complement receptor 1 , C1-inhibitor, C5, C9 and C1q}

The plasma levels of soluble complement receptor 1 (sCR1), C1-inhibitor (C1inh), C5, C9 and C1q were determined using optimised antibody pairs in sandwich ELISAs developed in-house. See Table 1 for details of each assay. Further information regarding our in house ELISA methods has been previously described [7].

Measuring the levels of $\mathrm{C} 3, \mathrm{C} 4$, factor $\mathrm{B}$, factor $\mathrm{H}$, factor I, factor $\mathrm{D}, \mathrm{Bb}, \mathrm{C} 3 \mathrm{a}$, iC3b, and terminal complement complex The majority of the complement proteins in this study were measured using customised v-plex assays from MesoScale Discovery (MSD; Rockville, Maryland,
USA), using antibody pairs developed in-house. C3, $\mathrm{C} 4$, factor $\mathrm{B}(\mathrm{FB})$, factor $\mathrm{H}(\mathrm{FH})$ and factor $\mathrm{I}(\mathrm{FI})$ were analysed together in multiplex 1 and factor $\mathrm{D}$ (FD), $\mathrm{Bb}$, C3a, iC3b and terminal complement complex (TCC) were analysed together in multiplex 2. All 8 analytes were measured by an electrochemiluminescence (ECL) immunoassay technique according to the manufacturer's protocol. In brief, pre-coated plates were blocked with $150 \mu \mathrm{l} /$ well $3 \%$ BSA in PBS at room temperature for $2 \mathrm{~h}$ with shaking at $600 \mathrm{rpm}$. Plasma samples were diluted 1:2000 for multiplex 1 and 1:2 for multiplex 2 in assay buffer (PBS containing 1\% BSA and $10 \mathrm{mM}$ EDTA) and $25 \mu \mathrm{l}$ aliquots were added in duplicate to wells. A calibration curve comprising a series of fivefold dilutions of protein standard was run in duplicate on each plate. Plates were incubated with shaking at $600 \mathrm{rpm}$ at room temperature for $60 \mathrm{~min}$. After washing in PBS containing $0.01 \%$ Tween $20,25 \mu \mathrm{l}$ of a mixture of the relevant SULFO-TAG-labelled detection antibodies diluted in assay buffer (1:100) was added and incubated with shaking at $600 \mathrm{rpm}$ at room temperature for $60 \mathrm{~min}$. After washing, $150 \mu \mathrm{l}$ of $2 \times$ MSD reading buffer was added to each well and ECL signal was measured on the Sector Imager 2400 (MSD).

Qc

All standards and samples for all assays were tested in duplicate. The intra-assay and inter-assay coefficients of variation (CV) \% were set at $25 \%$ and data for any sample with a $\mathrm{CV}$ above this was not included.

\section{Statistical analysis}

Protein concentrations were determined automatically from standard curves plotted using GraphPadPrism5. The units of concentration for all analytes shown are nanogram per milliliter. Spearman correlation tests were used in GraphPadPrism 5 to identify correlations between protein levels and time in freezer.

Table 1 In-house ELISAs

\begin{tabular}{|c|c|c|c|c|}
\hline Analyte & Capture antibody & Detection antibody & Standard curve & Plasma dilution \\
\hline sCR1 & $1 \mu \mathrm{g} / \mathrm{ml}$ RP anti-CR1 & $\begin{array}{l}1 \mu \mathrm{g} / \mathrm{ml} \text { MM HRP labelled anti-human } \\
\text { CR1 }\end{array}$ & $\begin{array}{l}50,25,12.5,6.25,3.125,1.565,0.78 \\
0 \mathrm{ng} / \mathrm{ml}\end{array}$ & $1: 2$ \\
\hline C5 & $1 \mu \mathrm{g} / \mathrm{ml}$ RP anti-C5 & $\begin{array}{l}1 \mu \mathrm{g} / \mathrm{ml} \text { MM HRP labelled anti-human } \\
\mathrm{C5}\end{array}$ & $\begin{array}{l}1000,500,250,125,62.5,31.25 \\
15.625,0 \mathrm{ng} / \mathrm{ml}\end{array}$ & $1: 100$ \\
\hline C9 & $1 \mu \mathrm{g} / \mathrm{ml} \mathrm{MM}$ anti-C9 & $\begin{array}{l}1 \mu \mathrm{g} / \mathrm{ml} \text { RP HRP labelled anti-human } \\
\mathrm{C} 9\end{array}$ & $\begin{array}{l}100,50,25,12.5,6.25,3.125,1.5625 \\
0 \mathrm{ng} / \mathrm{ml}\end{array}$ & $1: 2000$ \\
\hline $\mathrm{C} 1 \mathrm{q}$ & $\begin{array}{l}2 \mu \mathrm{g} / \mathrm{ml} \text { MM anti-C1q (commercial } \\
\text { WL02 from Hycult) }\end{array}$ & $\begin{array}{l}1 \mu \mathrm{g} / \mathrm{ml} \text { RP HRP labelled anti-human } \\
\mathrm{Clq}\end{array}$ & $\begin{array}{l}1000,500,250,125,62.5,31.25 \\
15.625,0 \mathrm{ng} / \mathrm{ml}\end{array}$ & $1: 800$ \\
\hline C1 inhibitor & $1 \mu \mathrm{g} / \mathrm{ml} \mathrm{MM}$ anti-C1 inhibitor & $\begin{array}{l}1 \mu \mathrm{g} / \mathrm{ml} \text { RP HRP labelled anti-human } \\
\mathrm{C} 1 \text { inhibitor }\end{array}$ & $\begin{array}{l}100,50,25,12.5,6.25,3.125,1.5625 \\
0 \mathrm{ng} / \mathrm{ml}\end{array}$ & $1: 16,000$ \\
\hline
\end{tabular}




\section{Results}

The concentrations of 18 complement biomarkers were measured in 720 plasma samples by solid-phase enzyme immunoassays. The means, ranges and standard deviations for each analyte are shown in Table 2. Results obtained are compatible with published values for these analytes, taking into account that this is a cohort of elderly individuals, many with significant pathology. A number of co-variables were considered in the analysis of the data, including length of storage of samples at $-80{ }^{\circ} \mathrm{C}$. The time the samples had been stored in the freezer before the measurement of biomarkers ranged from 6.6 to 10.6 years (mean 9.1. SD 0.6). The samples had not undergone any previous freeze-thaws and were transferred from the collection centres frozen on dry ice.

The cohort was tested for correlations between individual biomarker levels and time in freezer (Table 3 and Additional file 1). With the exception of five analytes (C4, C9, sCR2, clusterin and CRP), storage time was significantly correlated with measured plasma value. For ten analytes: C3, FI, FB, FD, C5, sCR1, C3a, iC3b, Bb and TCC, storage time was positively correlated, samples yielding significantly higher concentrations with longer time in the freezer. Using a linear model it was determined that concentration was increased for each year a sample was stored in the freezer by $30.3 \%(304,216 \mathrm{ng} /$ $\mathrm{ml}$ ) for C3, 8.1\% (2808 $\mathrm{ng} / \mathrm{ml})$ for FI, 5.2\% (5413 ng/ml) for $\mathrm{FB}, 5.8 \%(123 \mathrm{ng} / \mathrm{ml})$ for $\mathrm{FD}, 5.4 \%(1418 \mathrm{ng} / \mathrm{ml})$ for C5, 4.4\% (0.53 ng/ml) for sCR1, 12.1\% (13 ng/ml) for C3a, 9.7\% (23 ng/ml) for iC3b, $6.1 \%(8 \mathrm{ng} / \mathrm{ml})$ for $\mathrm{Bb}$ and $12.3 \%$ $(16 \mathrm{ng} / \mathrm{ml})$ for TCC. The storage time was negatively correlated with three of the proteins: $\mathrm{FH}, \mathrm{Clq}$, and $\mathrm{Clinh}$ which all displayed statistically significant lower concentrations with longer time in the freezer. Using a linear model it was determined that concentration decrease for each year a sample was stored in the freezer was $4.5 \%$ $(11,452 \mathrm{ng} / \mathrm{ml})$ for $\mathrm{FH}, 7.5 \%(13,285 \mathrm{ng} / \mathrm{ml})$ for $\mathrm{C} 1 \mathrm{q}$ and $2.8 \%$ (6710 for $\mathrm{ng} / \mathrm{ml}$ ) for C1inh.

\section{Discussion}

Many plasma samples are stored for a number of years in the freezer before their use in biomarker studies and there are questions regarding how stable complement analytes are during long-term storage at $-80{ }^{\circ} \mathrm{C}$. As part of our work program we had measured a large panel of complement biomarker analytes in a relatively large plasma set that had been stored at $-80{ }^{\circ} \mathrm{C}$ for between 6.6 and 10.6 years. As part of a post hoc analysis of extrinsic factors (co-variables) affecting the analyses we investigated the impact of freezer storage time on the values obtained for each complement analyte. Of the 18 analytes measured, ten had increased levels with longer time of storage at $-80{ }^{\circ} \mathrm{C}$, three had decreased levels
Table 2 Means and range of protein levels $(\mathrm{ng} / \mathrm{ml}$ )

\begin{tabular}{lrrrrr}
\hline Analyte & n & \multicolumn{1}{l}{ Min } & \multicolumn{1}{l}{ Max } & \multicolumn{1}{l}{ Mean } & \multicolumn{1}{l}{ SD } \\
\hline C3 & 690 & 235,097 & 8423,462 & 1004,059 & 528,689 \\
FI & 701 & 7419 & 69,773 & 34,876 & 8314 \\
FB & 695 & 27,419 & 295,598 & 103,430 & 28,238 \\
FD & 719 & 1092 & 4695 & 2125 & 607 \\
C5 & 720 & 13,405 & 47,415 & 26,369 & 5458 \\
SCR1 & 715 & 4 & 38 & 12 & 4 \\
C3a & 703 & 38 & 339 & 109 & 46 \\
iC3b & 571 & 38 & 726 & 240 & 133 \\
Bb & 719 & 50 & 1325 & 128 & 81 \\
TCC & 717 & 32 & 2941 & 132 & 252 \\
FH & 674 & 69,782 & 630,889 & 252,816 & 72,781 \\
C1q & 720 & 33,250 & 363,624 & 177,275 & 44,275 \\
C1 inhibitor & 719 & 81,192 & 673,570 & 236,527 & 59,156 \\
C4 & 702 & 32,722 & 719,480 & 174,190 & 78,337 \\
C9 & 719 & 23,542 & 268,083 & 81,610 & 29,727 \\
SCR2 & 712 & 46 & 625 & 175 & 70 \\
Clusterin & 720 & 112,694 & 532,722 & 226,729 & 42,704 \\
CRP & 702 & 70 & 11,864 & 1255 & 1422 \\
\hline
\end{tabular}

and five were not significantly changed. Notably, all four of the complement activation products $(\mathrm{C} 3 \mathrm{a}, \mathrm{iC} 3 \mathrm{~b}, \mathrm{Bb}$, TCC) included in the analysis were strongly positively correlated with storage time-all increased significantly in measured level. This suggests that there is significant "activation" of complement in EDTA plasma on longterm storage even at $-80^{\circ} \mathrm{C}$.

The study we report here is not without its limitations, the main one being that only one sample per subject was available. The best approach may be to measure samples at the time of collection and periodically thereafter using aliquots of the same samples on the same assay platform. However, such an experimental set-up is logistically difficult and even this is not without its own limitations as when comparing measurements taken at different times it is difficult to control for the variability this introduces. Measurements taken years later will be taken with different reagent batches and more than likely by different personnel.

There are few reports on the impact of storage time on levels of individual complement analytes and with only very small sample sets. Mollnes and co-workers made a pool of EDTA plasma obtained from 40 healthy blood donors; they stored the plasma for 3 years at $-70{ }^{\circ} \mathrm{C}$, and compared with a similar fresh pool. When examined together, these two pools showed exactly the same amount of $\mathrm{C} 3$ activation products $(15 \mathrm{AU} / \mathrm{ml})$ and TCC (5 AU/ml) [2]. In another study of storage of 88 plasma samples at $-80^{\circ} \mathrm{C}$ for $0-6$ years, no significant effect of length of storage time was found on levels of complement 
Table 3 Test for correlation between analytes and time in freezer

\begin{tabular}{lccr}
\hline Analyte & Spearman $\boldsymbol{r}$ & $\mathbf{9 5 \%}$ Cl & $\mathbf{p}$ \\
\hline C3 & 0.36 & 0.29 to 0.42 & $<0.0001$ \\
FI & 0.22 & 0.14 to 0.29 & $<0.0001$ \\
FB & 0.14 & 0.06 to 0.21 & 0.0003 \\
FD & 0.13 & 0.06 to 0.21 & 0.0003 \\
C5 & 0.14 & 0.07 to 0.21 & 0.0001 \\
sCR1 & 0.09 & 0.02 to 0.17 & 0.0118 \\
C3a & 0.17 & 0.09 to 0.24 & $<0.0001$ \\
iC3b & 0.1 & 0.02 to 0.19 & 0.0142 \\
Bb & 0.15 & 0.07 to 0.22 & $<0.0001$ \\
TCC & 0.27 & 0.20 to 0.34 & $<0.0001$ \\
FH & -0.11 & -0.18 to -0.03 & 0.0056 \\
C1q & -0.1 & -0.18 to -0.03 & 0.0064 \\
C1 inhibitor & -0.09 & -0.16 to -0.01 & 0.0197 \\
C4 & 0.003 & -0.07 to 0.08 & 0.93 \\
C9 & -0.05 & -0.13 to 0.02 & 0.17 \\
sCR2 & -0.02 & -0.09 to 0.06 & 0.63 \\
Clusterin & -0.01 & -0.09 to 0.07 & 0.75 \\
CRP & 0.03 & -0.05 to 0.10 & 0.51 \\
\hline
\end{tabular}

activation products $\mathrm{C} 3 \mathrm{a}, \mathrm{C} 4 \mathrm{~d}, \mathrm{C} 5 \mathrm{a}, \mathrm{TCC}(\mathrm{C} 5 \mathrm{~b}-9$ in this study) and $\mathrm{Bb}$ [8]. Our samples had been stored for longer than those in the described studies and this might explain in part the differences between our observations and those in these published studies. More likely is that in our study, the power provided by the large sample set (720 samples), and number of analytes, reveals storage effects not apparent in the published smaller studies.

There are further reports on the impact of storage time on non-complement biomarkers. One study reported that a 4-year difference in long-term storage had minimal effect on protein in plasma [9] while three other studies did report changes in protein biomarker levels with storage time. One study performed a time course analysis of cytokines, chemokines and growth factors measured in the banked serum of healthy donors and melanoma patients stored for various intervals, and analysed by multiplex Luminex assays. Seven of the ten analytes examined showed highly significant changes during the approximately 5 years of storage at $-80^{\circ} \mathrm{C}$ [10]. Enroth and co-workers found that plasma values of 18 of 108 protein biomarkers investigated were influenced by storage time (storage time 2-28 years) [11], while Kugler et al. found that levels of two serum markers measured at sample collection and again in the same samples after approximately 10 years in storage increased by $15 \%$ [12] . Taken together, these findings demonstrate that storage time needs to be a consideration in all biomarker studies using stored plasma samples, not just those focussing on complement.

If the effects of storage can be modelled then it may be possible to introduce a correction factor for time of storage that "normalises" the data and permits the use of samples stored for different times without compromising a study. When analysing our own data further we plan to adjust the complement concentrations observed based on linear models and estimate the concentration of each sample based on a time in freezer measure of 9 years, chosen because it represents the mean time of storage in the study, thus minimising the applied adjustment.

\section{Conclusions}

The key finding of this study is that long-term storage of plasma even at $-80^{\circ} \mathrm{C}$ alters levels of some complement components and all complement activation products. These effects must be taken into consideration when analysing data from historical sample sets spanning long periods of storage time, the case in most biobanks and other archived collections. Information on storage time must be regarded as an important co-variable, just as important as patient age or gender, and taken into consideration (and corrected for) when analysing data to look for associations of complement biomarker levels and disease or other outcomes.

\section{Additional file}

Additional file 1. Scatterplots of the levels of complement biomarkers measured in plasma depending on freezer storage time

\section{Abbreviations}

C1 inh: C1-inhibitor; CRP: C-reactive protein; CV: coefficients of variation; FB: factor B; FH: factor H; Fl: factor I; sCR1: soluble complement receptor 1; sCR2: soluble complement receptor 2; TCC: terminal complement complex.

\section{Authors' contributions}

ARM was involved in conceptualising and designing the study, carried out the biomarker assays, conducted the analysis and was primary author of the manuscript. $\mathrm{COH}$ worked on the biomarker assays. ST assisted with the data analysis. SL established the AddNeuroMed cohort and its data collection and contributed to editing of the manuscript. BPM was involved in conceptualising the study and critically appraising the manuscript. All authors read and approved the final manuscript.

\section{Author details}

${ }^{1}$ Division of Infection and Immunity, School of Medicine, Cardiff University, Heath Park, CF14 4XN, Cardiff, UK. ${ }^{2}$ Department of Psychiatry, University of Oxford, Oxford, UK.

\section{Acknowledgements}

This publication incorporates results from the research project entitled "Wellcome Trust Consortium for Neuroimmunology of Mood Disorders and Alzheimer's Disease" which is funded by a grant from the Wellcome Trust (104025).

The AddNeuroMed plasma samples were provided by the NIHR Biomedical Research Centre and NIHR Dementia Biomedical Research Unit hosted at Kings College London and South London and Maudsley NHS Foundation Trust and funded by the National Institute for Health Research under its Biomedical Research Centres initiative. 


\section{Competing interests}

The authors declare that they have no competing interests.

\section{Availability of data and materials}

All data generated or analysed during this study are included in this published article.

\section{Consent for publication}

Not applicable. Data is anonymised and cannot be linked to individual participants.

\section{Ethics approval and consent to participate}

The AddNeuroMed project is part of the InnoMed European Union FP6 programme, designed to develop and validate novel surrogate markers in AD. Consent was requested for data collection, sample storage and subsequent use of samples for research into plasma based biomarkers for Alzheimer's disease. Written consent was obtained where the research participant had capacity, and in those cases where dementia compromised capacity then assent from the patient and written consent from a relative, according to local law and process, was obtained. The AddNeuroMed project was approved by ethical review boards in each participating country (local ethical review board at University of Perugia, University of Toulouse, Aristotle University of ThessaIoniki, Medical University of Lodz, University of Eastern Finland and University Hospital of Kuopio and King's College London). The data were anonymised before being shared.

\section{Funding}

This study was funded by a grant from the Wellcome Trust (104025).

\section{Publisher's Note}

Springer Nature remains neutral with regard to jurisdictional claims in published maps and institutional affiliations.

Received: 13 December 2016 Accepted: 31 October 2017

Published online: 06 November 2017

\section{References}

1. Mollnes TE, Jokiranta TS, Truedsson L, Nilsson B, Rodriguez de Cordoba S, Kirschfink M. Complement analysis in the 21st century. Mol Immunol. 2007:44(16):3838-49.
2. Mollnes TE, Garred P, Bergseth G. Effect of time, temperature and anticoagulants on in vitro complement activation: consequences for collection and preservation of samples to be examined for complement activation. Clin Exp Immunol. 1988;73:484-8.

3. Baatrup G, Sturfelt G, Junker A, Svehag SE. Effects of coagulation temperature on measurements of complement function in serum samples from patients with systemic lupus erythematosus. Ann Rheum Dis. 1992;51:892-7

4. Nilsson B, Ekdahl KN. Complement diagnostics: concepts, indications, and practical guidelines. Clin Dev Immunol. 2012;2012:962702.

5. Lovestone S, Francis P, Kloszewska I, Mecocci P, Simmons A, Soininen H, Spenger C, Tsolaki M, Vellas B, Wahlund LO, Ward M, AddNeuroMed Consortium. AddNeuroMed-the European collaboration for the discovery of novel biomarkers for Alzheimer's disease. Ann NY Acad Sci. 2009;1180:36-46.

6. Simmons A, Westman E, Muehlboeck S, Mecocci P, Vellas B, Tsolaki M, Kłoszewska I, Wahlund LO, Soininen H, Lovestone S, Evans A, Spenger C, AddNeuroMed Consortium. MRI measures of Alzheimer's disease and the AddNeuroMed study. Ann N Y Acad Sci. 2009;1180:47-55.

7. Morgan AR, Touchard S, O'Hagan C, Sims R, Majounie E, Escott-Price V, Jones L, Williams J, Morgan BP. The Correlation between inflammatory biomarkers and polygenic risk score in Alzheimer's Disease. J Alzheimers Dis. 2017;56(1):25-36.

8. Yang S, McGookey M, Wang Y, Cataland SR, Wu HM. Effect of blood sampling, processing, and storage on the measurement of complement activation biomarkers. Am J Clin Pathol. 2015;143:558-65.

9. Mitchell BL, Yasui Y, Li Cl, Fitzpatrick AL, Lampe PD. Impact of freeze-thaw cycles and storage time on plasma samples used in mass spectrometry based biomarker discovery projects. Cancer Inform. 2005;1:98-104.

10. Butterfield LH, Potter DM, Kirkwood JM. Multiplex serum biomarker assessments: technical and biostatistical issues. J Transl Med. 2011;9:173.

11. Enroth S, Hallmans G, Grankvist K, Gyllensten U. Effects of long-term storage time and original sampling month on biobank plasma protein concentrations. EBioMedicine. 2016;12:309-14 (Epub ahead of print).

12. Kugler KG, HackI WO, Mueller LA, Fiegl H, Graber A, Pfeiffer RM. The impact of sample storage time on estimates of association in biomarker discovery studies. J Clin Bioinforma. 2011;1:9.

\section{Submit your next manuscript to BioMed Central and we will help you at every step:}

- We accept pre-submission inquiries

- Our selector tool helps you to find the most relevant journal

- We provide round the clock customer support

- Convenient online submission

- Thorough peer review

- Inclusion in PubMed and all major indexing services

- Maximum visibility for your research

Submit your manuscript at www.biomedcentral.com/submit
Biomed Central 